\title{
Factors Influencing Environmental Accounting Information Disclosure of Listed Enterprises on Vietnamese Stock Markets*
}

\author{
Tung Dao NGUYEN ${ }^{1}$
}

Received: August 01, 2020 Revised: September 30, 2020 Accepted: October 15, 2020

\begin{abstract}
The purpose of the article is to evaluate the factors that affect the degree of environmental accounting information disclosure. Data are collected from 87 industry companies listed on the Vietnamese stock market from 2009 to 2019. I focus on the effect of factors such as the Firm size, Profitability, Leverage, Firm age, and Independent auditors. To explain the causal relationship between factors, I construct the regression model and then test it by using different statistical method approaches, including the pooled OLS, the fixed effects model, and the random effects model. Then I conduct testing of model defects: White Test, Wooldridge Test, Hausman Test, and Wald Test. The Feasible Generalized Least Squares (FGLS) method is used to analyze the image factors that affect environmental accounting information disclosure. The results show that the extent of environmental accounting information disclosure is influenced by factors: firm size, uptime and independent audit. These factors positively affect the level of environmental accounting information disclosure; independent audit has the greatest influence. Based on the research results, the author gives recommendations to improve the disclosure of environmental accounting information for industrial enterprises listed on the Vietnamese stock market, increasing the competitiveness of the public company in terms of global integration.
\end{abstract}

Keywords: Environmental Accounting, Information Disclosure, Industrial Enterprises

JEL Classification Code: G30, M40, M41

\section{Introduction}

Environmental accounting is a growing field that seeks and provides important and necessary information on environmental costs and revenues, and guides businesses and project owners in making economic decisions, encouraging them to make efforts to use natural resources, including natural resources created by man, effectively and minimizing

\footnotetext{
*Acknowledgements:

The author is thankful to Academy of Finance for funding this research. I would like to thank the anonymous referees for their helpful comments and suggestions.

${ }^{1}$ First Author and Corresponding Author. Deputy Director, Academy of Finance, Vietnam [Postal Address: 58 Le Van Hien Road, Bac Tu Liem District, Hanoi, 130500, Vietnam]

Email: nguyendaotungsci@hvtc.edu.vn

() Copyright: The Author(s)

This is an Open Access article distributed under the terms of the Creative Commons Attribution Non-Commercial License (https://creativecommons.org/licenses/by-nc/4.0/) which permits unrestricted non-commercial use, distribution, and reproduction in any medium, provided the original work is properly cited.
}

environmental damage, minimizing waste and pollution, and changing behaviors towards living environment.

Enterprises are aware of the socio-economic development that must protect the environment, but the environmental information presented in the company's annual reports is limited, as is the degree of environmental accounting information disclosure. The number of companies listed in Vietnam on reports and on the website is relatively low. Nurul Huda (2015) found that corporations with high profits often disclose environmental accounting information more than others. Khalid et al (2015) argued that there should be pressure, an imperative to force businesses to comply with environmental activities.

Vietnam's industry has experienced a strong growth with the highest growth rate in recent years. The industries with great prospects are identified as industries serving industrialization and modernization, industries involved to advanced technology, contributing to growth and to GDP. At present, the supporting industry is identified as a promising industry. There are many competitive advantages, exports have grown continuously and developed towards participation in international supply chains, large domestic 
markets. A strong wave of overseas investment from foreign businesses, especially from Japan and South Korea, is greatly benefiting from Free Trade Agreements such as TPP, AFTA, Vietnam-ASEAN-EU, which are about to be signed and through which Vietnam will enjoy preferential policies, offering great opportunity for Vietnamese industry.

Facing the opportunity for faster development, disclosure and transparency of information on environmental accounting of industrial enterprises is necessary, as it is a measure for industrial companies to improve their reputation and image with domestic and foreign partners. Recognizing the importance of this activity, Vietnamese companies have been focusing more on the implementation of environmental accounting. However, the level of environmental accounting information disclosure of companies listed on the Vietnamese stock market has not met the expectations of related parties. Therefore, this study aims to examine and evaluate the factors affecting the level of environmental accounting information disclosure in industrial companies listed on the stock market of Vietnam. The research contributes to propose directions and effective solutions to promote the implementation and transparency of environmental accounting information by industrial companies in the coming time.

\section{Literature Review and Hypotheses}

\subsection{Theories Related to Environmental Accounting Information Disclosure}

Theories that explain the disclosure of environmental accounting information include voluntary information disclosure theory, institutional theory, legal theory, corporate social responsibility theory, and stakeholder theory.

\section{(1) Voluntary disclosure theory}

The voluntary disclosure theory states that the purpose of voluntary disclosure is for environmental practices information to be passed on to shareholders (Bewley \& $\mathrm{Li}$, 2000). Companies effectively use the target environment as a way to convey information, hoping that the contents of the environmental performance announcement can be positively related to the environmental performance, and hopefully through disclosure of environmental information will transfer a company's environmental strategy to shareholders (Clarkson et al., 2008).

\section{(2) Institutional theory}

Theoretical view of institutions, mainly based on social and economic theoretical perspectives (DiMaggio \& Powell, 1983). This theory explores how organizational structures and actions are shaped by institutional forces, such as Government, professional agencies and society around the institutions. There are three possible pressures: coercive pressure, imitation pressure, and normative pressure.

\section{(3) Legitimacy theory}

Legal theory states that, for a company to continue to operate successfully, it must act within the boundaries and norms that society defines as socially-responsible behavior (O’Donovan, 2002). Deegan and Unerman (2011) define legal theory as the "social contract" between an organization and the society in which it operates. In such an environment, companies try to legitimize their actions by participating in corporate social responsibility reports, for social approval (Omran \& Ramdhony, 2015). Institutional theory has laid the foundations for legitimacy because it views many of the organization's activities as the driving force to seek legitimate behavior, and is therefore influenced by social norms.

\section{(4) Corporate Social Responsible theory}

Corporate social responsibility was published by Bowen and Johnson in their 1953 book Social Responsibilities of the Businessmen. They call to propagate and urge property managers not to harm the rights and interests of others, to appeal to charity to compensate for damages caused by businesses harming society.

\section{(5) Stakeholder theory}

Stakeholder theory was first introduced by Freeman (1984) in his work on strategic management. Related parties include any person or group of people who are interested in the company, as they may influence or be influenced by the company. Freeman divides stakeholders with related interests and obligations into two groups: inside and outside the business. Managers and employees are stakeholders inside the business; stakeholders outside the business are shareholders, suppliers, and government agencies. The stakeholder theory has many applications; one application in the field of accounting that believes a company's success depends on the cooperation of its stakeholders, because they provide tangible or intangible resources to ensure the survival of the firm. These resources can be financial resources (shareholders), operating environment and public services (government agencies), and labor (employees). Therefore, the company is accountable to providing information explaining a company's business to stakeholders, rather than simply providing information to the owner.

\subsection{Literature Review}

Studies on factors affecting the degree of voluntary disclosure of information related to the environment and society include Arif and Tuhin (2013), Barakat et al. 
(2015), Yang and Liang, (2017). The research results show that factors such as years of service, annual profitability, firm size, profitability, debt management coefficient, and ISO14001 certificates have a significant impact on the degree of publication. Voluntary information relate to the environment and society in which the business operates.

Barakat et al. (2015) explained that the difference in the degree of disclosure between companies is due to the legal system, the company's performance characteristics, the characteristics of the audit firm, independence, and corporate governance characteristics.

Shane and Spicer (1983) show that relatively large companies publish more environmental accounting information in their annual reports. Companies that do not disclose environmental accounting information are lacking a recognized disclosure framework, disclosure costs, and user responses to claims.

For companies listed in the Netherlands, corporate profits are not statistically significant in relation to the extent to which environmental accounting information is disclosed, while firm size has a significant effect. It is related to the extent to which environmental accounting information is disclosed (Burgwal \& Vieira, 2014).

Nurul Huda (2015) said that the disclosure of environmental accounting information of companies is influenced by the law, the size of the business, the profitability, and the abundant amount of money. In general, companies can adhere to any government initiative for a sustainable economy, as long as the company is financially secure.

\subsection{Research hypotheses}

Based on Literature Review, the author gives the following research hypotheses:

H1: Firm size has a positive relationship with the degree of environmental accounting information disclosure

H2: Profitability has a positive relationship with the level of environmental accounting information disclosure

H3: Financial leverage has an inverse relationship with the level of environmental accounting information disclosure

H4: The operation time has a positive relationship with the level of environmental accounting information disclosure

H5: Audit quality has a positive relationship with the level of environmental accounting information disclosure

\section{Research Method}

\subsection{Research Data}

The study used panel data collected from 87 industrial enterprises listed on Vietnam Stock Market over an 11-year period, from 2009 to 2019, provided by FiinGroup JSC. Research data is extracted from the audited financial statements of these enterprises. Environmental accounting information is published and taken from annual reports, durable reports and corporate governance reports, which are publicly available on the website of the 87 companies in the sample.

\subsection{Measurement of Variables}

Table 1: Definition of model variables

\begin{tabular}{|c|c|c|c|}
\hline Variable name & Code & Measurement & $\begin{array}{l}\text { Hypothesized } \\
\text { sign }\end{array}$ \\
\hline $\begin{array}{l}\text { Disclosure level } \\
\text { disclosure of environmental } \\
\text { accounting information }\end{array}$ & ENVI & $\begin{array}{l}=1 \text {, firm The enterprise has disclosed environmental } \\
\text { accounting information; }=0 \text {, the rest. }\end{array}$ & \\
\hline Firm size & SZ & Ln(total asset) & + \\
\hline Profitability & PRO & Net income/average total asset & + \\
\hline Leverage & LEV & Current liability/total liability & - \\
\hline Firm age & AGE & Year of research - year of establishment & + \\
\hline Independent auditors & ID & $=1$, independent auditor of Big $4 ;=0$, the rest. & + \\
\hline
\end{tabular}

\subsection{Research Method}

To achieve the research goal to identify the factors that affect the degree of accounting information disclosure research environment and to test the hypotheses $\mathrm{H} 1$ to $\mathrm{H} 5$, the Stata software for data analysis is used. Linear regression method multivariate is applied with the following model:

$$
\begin{aligned}
\text { ENVIit }= & \beta 0+\beta 1 \text { SIZEit }+\beta 2 \text { PROit }+\beta 3 \text { LEVit } \\
& +\beta 4 \text { AGEit }+\beta 5 \text { IDit }+ \text { eit }
\end{aligned}
$$

To explain the causal relationship between factors, I construct the regression model and then test it by using different statistical approaches, including the pooled OLS, the fixed effects model, and the random effects model. 
Then I conduct testing of model defects with White Test, Wooldridge Test, Hausman Test, and Wald Test. The Feasible Generalized Least Squares (FGLS) method is used to analyze the image factors that affect environmental accounting information disclosure.

\section{Empirical Results}

\subsection{Descriptive Statistics}

Table 2 reports the overall observations, mean, standard deviation, minimum, and maximum values.

Table 2 shows that the average score of environmental accounting disclosure is 0.2894 , and ranges from 0 to 1 . The results imply that environmental awareness can be increased using activities on sustainability issues (Khan et al., 2020). Firm size is from 23.46 to 30.61 , demonstrating that the size of the firms in the sample is quite diverse and there is quite a large difference. The level of using short-term debt of the business is quite high at 0.813 and fluctuates from 0.1417 to present, which shows that there is a large difference in the level of using short-term debt of the industrial enterprises listed on the Vietnam stock market. Service life of businesses has an average of 7.62 years and the longest is 46 years. This proves that the enterprises in the sample have not been too young for listing time on the stock market. The Big 4 group of independent auditors was at the average level of 0.201 .

\subsection{Correlation Analysis}

Table 3 presents the results of testing the correlation coefficients among the variables. The results show that there is an correlation between the independent and dependent variables of the model; the level of environmental accounting information disclosure is positively related or positively correlated with the variables: firm size, shortterm debt utilization, uptime, and independent audit, and negative correlation with profitability. At the same time, the correlated pairs of variables are less than 0.8 and the variance magnification coefficient (VIF) of the independent variables are all $<5$, which proves that there is no phenomenon multicollinearity between the variables.

\subsection{Regression Results}

Table 4 presents the regression results using the least squares method (OLS), Fixed effects model (FEM), Random effects model (REM) and Feasible Generalized Least Squares (FGLS). The results show that there are differences between the four methods above.

Table 2: Descriptive statistics of the variables

\begin{tabular}{|l|c|c|c|c|c|}
\hline Variables & Obs & Mean & Std. & Min & Max \\
\hline ENVI & 957 & 0.2894 & 0.4537 & 1 \\
\hline SZ & 957 & 26.6381 & 1.1967 & 23.4619 & 30.607 \\
\hline PRO & 957 & 0.0759 & 0.094 & -8.998 & 0.7426 \\
\hline LEV & 957 & 0.8193 & 0.2237 & 0.1417 & 1 \\
\hline AGE & 957 & 13.43 & 7.6222 & 0 & 4 \\
\hline ID & 957 & 0.201 & 0.401 & 0 & 1 \\
\hline
\end{tabular}

Table 3: Correlation coefficient matrix between the variables in the model

\begin{tabular}{|l|c|c|c|c|c|c|c|}
\hline & ENVI & SZ & PRO & LEV & AGE & ID & VIF \\
\hline ENVI & 1 & & & & & & \\
\hline SZ & 0.2624 & 1 & & & & & 1.49 \\
\hline PRO & -0.0981 & -0.0293 & 1 & & & & 1.03 \\
\hline LEV & 0.0122 & -0.4322 & 0.0906 & 1 & & & 1.26 \\
\hline AGE & 0.1540 & 0.0736 & -0.1252 & -0.0031 & 1 & & 1.04 \\
\hline ID & 0.5836 & 0.3979 & -0.0368 & -0.0815 & -0.0811 & 1 & 1.23 \\
\hline
\end{tabular}


Table 4: Regression results

\begin{tabular}{|c|c|c|c|c|}
\hline \multirow{2}{*}{ Variables } & \multicolumn{4}{|c|}{ Dependent variable (IR) } \\
\hline & POLS & FEM & REM & FGLS \\
\hline SZ & $0.0201^{*}$ & $-0.0997^{* * *}$ & $0.0262^{*}$ & $0.002^{*}$ \\
\hline PRO & $-0.286^{* *}$ & -0.0299 & $-0.346^{* *}$ & 0.0379 \\
\hline LEV & $0.180^{* * * *}$ & -0.0227 & $0.195^{* * *}$ & 0.0048 \\
\hline AGE & $0.0113^{* * *+}$ & $0.0755^{* * *}$ & $0.0172^{\text {*t*t }}$ & $0.00874^{* * * *}$ \\
\hline ID & $0.660^{* * *}$ & $0.643^{*+* x}$ & $0.686^{* * *+}$ & $0.617^{* * *}$ \\
\hline Cons & $-0.656^{* *}$ & $1.825^{*+*}$ & $-0.909^{* *}$ & $-0.0027^{*+*}$ \\
\hline $\mathrm{N}$ & 957 & 957 & 957 & 957 \\
\hline Significance & $F(7,147)=20.30$ & $F(7,379)=11.88$ & & Wald chi2 $(7)=36.49$ \\
\hline White Test & $\begin{array}{c}\text { Chi2 }(19)=140.07 \\
\text { Prob }>\text { Chi2 }=0.0000\end{array}$ & & & \\
\hline Wooldridge Test & $\begin{array}{l}F(1,86)=11.708 \\
\text { Prob }>F=0.0010\end{array}$ & & & \\
\hline Hausman Test & & $\begin{array}{c}\text { chi2 }(5)=461.14 \\
\text { Prob }>\text { chi2 }=0.0000\end{array}$ & & \\
\hline Wald Test & & $\begin{array}{l}\text { chi2 }(87)=1593.62 \\
\text { Prob }>\text { chi2 }=0.0000\end{array}$ & & \\
\hline
\end{tabular}

Note: $\left({ }^{*}\right),\left({ }^{* *}\right),\left({ }^{* *}\right)$ represent for the significant level at $1 \%, 5 \%$ and $10 \%$, respectively.

The White test shows that the model has heterogeneity phenomenon ( $\mathrm{p}$-value $<5 \%$ ), the Wooldridge test shows that the model has the phenomenon of variance of variation (p-value $<5 \%$ ). Therefore, the Pool OLS model is not suitable. The Hausman test for $\mathrm{p}$-value $=0.000<0.05$ rejects Ho, so using FEM analyzed the factors that affect the degree of disclosure of accounting information reported by the listed businesses. After selecting FEM as the appropriate model, the author performed a model defect test with the Wald test. The results obtained prob $>$ chi $2=0.0000<0.05$, showing that the FEM model has defects. The author has analyzed regression according to FGLS method to analyze the factors affecting the level of environmental accounting information disclosure of listed enterprises.

The FGLS model research results show the following:

Enterprise size positively affects the level of environmental accounting information disclosure of industry enterprises listed on the stock market with the significance level of $10 \%$. This result is consistent with research by Jamil et al. (2005) and Barakat et al. (2015). When the size of the enterprise increases by $1 \%$, the level of environmental accounting information disclosure increases by $0.002 \%$. This shows that the impact of business size on the level of environmental accounting information disclosure is not great. The results also found that firm size (SIZE) and profitability (PRO) positively and insignificantly affect the disclosure level of EAI, while leverage (LEV) negatively and insignificantly affect it (Nguyen et al., 2020)

Profitability of enterprises positively affects the level of environmental accounting information disclosure of industrial enterprises listed on the stock market, but it is not statistically significant. This shows that the impact of profitability on the level of environmental accounting information disclosure is negligible.

The extent of using short-term debt positively affects the level of environmental accounting information disclosure by industrial enterprises listed on the stock market, but is not statistically significant. This shows that the impact of shortterm debt usage on environmental accounting information disclosure is negligible.

The operating time of the business positively affects the level of environmental accounting information disclosure of the industry enterprises listed on the stock market with the significance of $1 \%$. This result is consistent with the research by Jamil et al. (2015), but it runs contrary to the research by Ferrero et al. (2015) who showed that the time company operates does not affect the degree of environmental accounting information disclosure.

Independent audit positively affects the level of environmental accounting information disclosure of industry enterprises listed on the stock market with the significance of $1 \%$. This shows that the impact of the independent audit 
by the Big 4 has a large impact on the level of environmental accounting information disclosure.

\section{Recommendations and Conclusion}

Based on the research results, the author proposes some recommendations as follows:

First, the size of the firm and the length of its operation have a positive impact on the level of environmental accounting information disclosure by industrial enterprises listed on the stock market. The larger the enterprises, the longer the operating time of the business, the higher the level of environmental accounting information disclosure. This also shows that stakeholders have greater expectations and requirements for large firms and long lifespans, which is an opportunity, but also a pressure for this firm. Therefore, in order to attract and maintain the advantage and position of the business, managers need to focus on investing appropriate resources for accounting and disclosure of information related to environmental accounting. In particular, it is necessary to propagate and raise awareness of environmental protection and social responsibility for the managers at all levels in the enterprise as well as the entire employees. At the same time, the enterprise size is also a significant influence on environmental information disclosure activities of listed companies on Vietnam's stock market (Nguyen et al., 2020).

Second, the choice of auditing firms has a great influence on the degree of environmental accounting information disclosure of the enterprise. The enterprise is audited by big firms in the group of four leading auditing firms in the world - Pricewaterhouse Coopers (PwC), Ernst and Young (EandY), Klynveld Peat Marwick Geordeler (KPMG) and Deloitte Touche Tohmatsu Limited (Deloitte) - often have a higher degree of environmental accounting disclosures than other firms. Therefore, the selection of an independent auditor is also an important factor that the Board of Directors needs to consider. It also enhances the reputation and image of the company toward related parties. This is also considered as a measure to contribute to improving environmental accounting in the business.

The paper examines the factors affecting the level of environmental accounting information disclosure of 87 industrial enterprises listed on the stock market of Vietnam over a 11-year period, from 2009 to 2019. The article contributes to richer studies on environmental accounting as well as contributes to promoting the release of environmental accounting information in industrial enterprises in Vietnam in the future.

\section{References}

Arif, H. M., \& Tuhin, M. H. (2013). Disclosure of non-financial information voluntarily in the annual report of financial institutions: A study on listed banks of Bangladesh. European Journal of Business and Economics, 8(2), 37-42. https://doi. org/10.12955/ejbe.v8i2.397.

Barakat, F. S. Q., Pérez, M. V. L., \& Ariza, L. R. (2015). Corporate social responsibility disclosure (CSRD) determinants of listed companies in Palestine (PXE) and Jordan (ASE). Review of Managerial Science, 9, 681-702. https://doi.org/10.1007/ s11846-014-0133-9

Bewley, K., \& Li, Y. (2000). Disclosure of environmental information by Canadian manufacturing companies: a voluntary disclosure perspective. Advances in Environmental Accounting and Management, 1(1), 201-226.

Bowen, H. (1953). Social responsibilities of the businessman. With a commentary by F. Ernest Johnson. New York, NY: Harper \& Brothers.

Burgwal, D. V.D., \& Vieira, R. J. O. (2014). Environmental disclosure determinants in Dutch listed companies. Revista Contabilidade and Finanças, 25(64), 60-78. https://www.scielo.br/scielo. php?script=sci_arttextandpid=S1519-70772014000100006

Clarkson, P. M., Li, Y., Richardson, G. D., \& Vasvari, F. P. (2008). Revisiting the relation between environmental performance and environmental disclosure: An empirical analysis. Accounting, organizations and society, 33(4-5), 303-327. https://doi. org/10.1016/j.aos.2007.05.003.

Deegan, C., \& Unerman, J. (2011). Unregulated corporate reporting decisions: considerations of systems-oriented theories. Financial Accounting Theory. London, UK: McGraw-Hill.

DiMaggio, P. J., \& Powell, W. W. (1983). And collective rationality in organizational fields. American Sociological Review, 48(2), 147-160. https://www.ics.uci.edu/ corps/phaseii/ DiMaggioPowell-IronCageRevisited-ASR.pdf.

Freeman, R. E. (1984). Stakeholder management: Framework and Philosophy. Mansfield, MA: Pitman.

Ferrero, M. J., Garcia-Sanchez, I. M., \& Cuadrado-Ballesteros, B. (2015). Effect of financial reporting quality on sustainability information disclosure. Corporate Social Responsibility and Environmental Management, 22(1), 276-283. https://doi. org/10.1002/csr.1330.

Jamil, C. Z. M., Mohamed, R., Muhammad, F., \& Ali, A. (2015). Environmental management accounting practices in small medium manufacturing firms. Procedia - Social and Behavioral Sciences, 172, 619-626. http://dx.doi.org/10.1016/j. sbspro.2015.01.411.

Khalid, F. M., Ahmad, N., \& Hasan, S. J. (2015). Awareness of environmental management accounting for decision making: A case study on an institution of higher learning. National Symposium \& Exhibition on Business \& Accounting 2015 (NSEBA IV).

Nguyen, T. M. H., Nguyen, T. K. T., \& Nguyen, T. T. V. (2020). Factors Affecting the Implementation of Environmental Accounting by Construction Companies Listed on the Ho Chi Minh Stock Exchange. Journal of Asian Finance, Economics 
and Business, 7(8), 269-280. https://doi.org/10.13106/ jafeb.2020.vol7.no8.269.

Nguyen, T. L. H., Nguyen, T. T. H., Nguyen, T. T. H., LE, T. H. A., \& Nguyen, V. C. (2020). The Determinants of Environmental Information Disclosure in Vietnam Listed Companies. Journal of Asian Finance, Economics and Business, 7(2), 21-31. https:// doi.org/10.13106/jafeb.2020.vol7.no2.21

Nurul Huda, Y. (2015). Determinants of environmental reporting in Malaysia for industrial product sector. Doctoral dissertation, Universiti Utara Malaysia. http://etd.uum.edu.my/id/ eprint $/ 5150$

O'donovan, G. (2002). Environmental disclosures in the annual report. Accounting, Auditing and Accountability Journal. https://doi.org/10.1108/09513570210435870.

Omran, M. A., \& Ramdhony, D. (2015). Theoretical perspectives on corporate social responsibility disclosure: a critical review.
International Journal of Accounting and Financial Reporting, 5(2), 38-55. DOI: 10.5296/ijafr.v5i2.8035.

Shane, P. B., \& Spicer, B. H. (1983). Market response to environmental information produced outside the firm. Accounting Review, 521-538. DOI: 10.2307/246532

Uzma, K. H. A. N., Haque, M. I., \& Khan, A. M. (2020). Environmental Sustainability Awareness in the Kingdom of Saudi Arabia. Journal of Asian Finance, Economics and Business, 7(9), 687-695. https://doi.org/10.13106/jafeb.2020. vol7.no9.687

Yang, L. H., \& Liang, X. T. (2017). Study on the influencing factors of environmental accounting information disclosure. Paper presented at the International Conference on Economics, Management Engineering and Marketing - EMEM 2017, October 20th-22nd. 